Jurnal Ilmu Keolahragaan Vol. 17 (2), Juli-Desember 2018: 62 - 72

\title{
PERBEDAAN PENGARUH LATIHAN LOMPAT GAWANG DAN NAIK TURUN TANGGA TERHADAP DAYA LEDAK OTOT TUNGKAI PADA ATLET EKSKUL ANGGAR MAN 2 MODEL MEDAN TAHUN 2018
}

\author{
Zen Fadli $^{1}$ Mubarok Kurrahman Ritonga ${ }^{2}$
}

\begin{abstract}
Abstrak : Penelitian ini bertujuan untuk mengetahui, perbedaan pengaruh latihan lompat gawang dan naik turun tangga terhadap daya ledak ototo tungkai atlet ekskul anggar man 2 model medan. Jenis penelitian ini merupakan penelitian eksperimen menggunakan metode eksperimen dengan menggunakan teknik total sampling dalam pengambilan sampel dan pengambilan data dengan menggunakan tes dan pengukuran. Ada dua variable bebas dalam penelitian ini yaitu latihan naik turun tangga dan latihan lompat gawang dan satu variable terikat yaitu otot tungkai..
\end{abstract}

Analisis data dilakukan dengan uji-t pada data pretest dan postest hasil tes kemampuan otot tungkai atlet ekskul anggar man 2 model medan. Hasil uji-t diperoleh nilai t-hitung sebesar 3.057 dan nilai t-tabel sebesar 1.83. Oleh karena nilai t-hitung lebih besar dari t-tabel $(3.057>1.83)$ maka dapat disimpulkan bahwa terdapat pengaruh latihan Lompat gawang terhadap daya ledak otot tungkai pada atlet ekskul anggar man 2 model medan. Nilai rata-rata untuk data pretest adalah sebesar 175,2 dan nilai rata-rata untuk data postest adalah sebesar 187,8. Dalam hal ini dapat disimpulkan peningkatan yang diberikan dengan Lompat gawang terhadap daya ledak otot tungakai atlet ekskul anggar man 2 model medan meningkat.

Dan Hasil uji-t diperoleh nilai t-hitung sebesar 3.587 dan nilai t-tabel sebesar 1.83. Oleh karena nilai t-hitung lebih besar dari t-tabel $(3.587>1.83)$ maka dapat disimpulkan bahwa terdapat pengaruh Latihan Naik turun tangga terhadap daya ledak otot tungkai pada atlet ekskul anggar man 2 model medan. Berdasarkan tabel di atas dapat diketahui bahwa nilai rata-rata untuk data pretest adalah sebesar 170,7 dan nilai rata-rata untuk data postest adalah sebesar 181,6. Dalam hal ini dapat lompat gawang dan naik turun tangga yang lebih pengaruh adalah lompat gawang dibanding naik turun tangga setelah dilihat dari perbandingan hasil pree test dan post test masing masing varians Lompat gawang dan Naik Turun tangga sebesar $12.6>10.9$.

\section{PENDAHULUAN}

Olahraga sekarang ini telah menjadi kebutuhan setiap individu karena melakukan kegiatan olahraga yang baik dan benar serta berkesinambungan dapat meningkat derajatkebugaran jasmani. Hal ini dapat dilihat dari antusias masyarakat disetiap kegiatankegiatan olahraga.Selain dapat meningkatkan kebugaran jasmani, olahraga prestasi juga dapat dijadikan sebagai alat untuk mengangkat harkat dan martabat.Penigkatan prestasi dalam suatu cabang olahraga harus didukung oleh kondisi fisik yang baik, penguasahan teknik khusus dan pisikologis.

Memiliki kondisi yang baik maka seseorang akan lebih mudah untuk mencapai prestasi maksimal. Hal ini di ungkapkan Sajoto (1998: 3), "bahwa salah satu factor penentu

\footnotetext{
${ }^{1}$ Penulis adalah Staf Edukatif Fakultas Ilmu Keolahragaan UNIMED

${ }^{2}$ Penulis adalah Guru Penjaskes
} 
Zen Fadli, Mubarok Kurrahman Ritonga : Perbedaan Pengaruh Latihan Lompat Gawang Dan Naik Turun Tangga Terhadap Daya Ledak Otot Tungkai Pada Atlet Ekskul Anggar Man 2 Model Medan Tahun 2018

dalam mencapai prestasi olahraga adalah terpenuhinya komponen fisik, yang terdiri dari kekuatan, kecepatan, kelincahan, tenaga (power), daya tahan otot, daya kerja jantung dan paru-paru, kelenturan, keseimbangan, dan kesehatan untuk berolahraga". Dengan demikian kondisi fisik yang baik, makaakan sangat mendukung aktivitas yang dilakukan. Seiring dengan banyaknya kegiatan pertandingan olahraga Anggar ditingkat Daerah, Nasional maupun Internasional, maka Anggar mengalami kemajuan teknik tusukan, strategi menyerang dan bertahan, serta tumpuhan yang kuat.Untuk mencapai salah satu cara yang tepat dilakukan adalah upaya pembinaan dini dan penerapan latihan yang terprogram secara sistematis,terarah dan berkesinambungan.

Didalam latihan sehari-hari pelatih anggar Man 2 Model Medan menerapkan system latihan fisikdan latihan teknik. Latihan fisik dilaksanakan 3 kali dalam seminggu yaitu jumat sampai dengan minggu, satu kali latihan dilaksanakan daripukul 03.00-05.15 WIB. Yang dilaksanakan di lapangan Man 2 Model Medan. Latihan teknik dilaksanakan 3 kali dalam seminggu yaitu jumat sampai dengan minggu, dua kali latihan di laksanakan dari pukul 03.00 - 05.15 wib dan pada hari minggu jam 08.00 - 10,00 wib. Yang dilaksanakan di lapangan Man 2 Model Medan.

Cabang olahraga anggar membutuhkan berbagai dasar - dasar macam latihan dan ilmu gerak tentang gerak. Dengan menggunakan pendekatan keilmuan maka hasil analisa gerakan yang akan mempermudah seseorang dalam mempelajari gerakan yang benar. Sesuai dengan urutannya bahwa olahraga anggar yang paling pertama yaitu teknik dasar tumpuhan atau posisi bertahan ataupun menyerang.Kemajuan dalam kepelatihan olahraga anggar pada saat ini cukup sangat baik.Banyak memberikan kontribusi dalam pengembangan bentuk aspek latihan fisik, tekhnik dan taktik/strategi serta mental dalam bertanding. Setiap masalah yang terjadi dihadapi dan diselesaikan.Dengan pembenahan diri, mengembangkan serta mengevaluasi dan memperbaiki dari beberapa sektor pendukung serta mencari metode agar berkompeten sesuai dengan perkembangan zaman.

Dari hasil observasi dilapangan tanggal 28 september sebanyak 5orang sebanyak $22 \%$ dari 20 orang atlet. Masih ada atlet ketika latihan masih banyak para atlet Man 2 Model Medan yang tidak melakukan kuda-kuda atau sikap dasar dalam cabang olahraga anggar.Ada yg berdiri tegak dan tidak melakukan setengah jongkok, sehingga pada saat bertahan atau pun menyerang tumpuhan kaki sangat lemah dan tolakkan yang kurang baik.

Hal tersebut disebabkan banyak faktor yang mempengaruhi, salah satunya adalah saat melakukan pemanasan awal masih kurang maksimal, beban latihan fisik yang diberikan pelatih masih kurang maksimal kepada atlet anggar Man 2 Model Medan, kurangnya variasi latihan yang diberikan oleh pelatih, kurangnya keseriusan dari anak didik dalam melakukan teknik latihan tumpuhan yang kuat, serta konsentrasi dalam melakukan serangan terhadap lawan kurang maksimal.

Tidak adanya latihan kekuatan otot tungkai yang diberikan oleh pelatih, sarana peralatan dan perlengkapan yang digunakan untuk kegiatan berlatih dengan senjata anggar dan prasarana tempat atau ruang termasuk lingkungan yang digunakan untuk kegitan latihan anggar. Ada juga atlet melakukan gerakan dengan benar namun pada saat dia melakukan gerakan menyerang atau maju dia tidak melakukan gerakan dengan baik. Dan dia tidak memaksimal kan otot tungkainya.

Berdasarkandari identifikasi masalah diatas,untuk menghindari salah penafsiran dalam penelitian ini, maka penulis membatasi masalah sebagai berikut: Untuk meningkatkan kualitas latihan pada atlet anggar Man 2 Model Medan khususnya dalam latihan daya ledak otot tungkai, maka penulis akan melakukan penelitian dengan melakukan variasi latihandaya ledak otot tungkai dangan latihan lompat gawang dan naik turun tangga. 
Jurnal Ilmu Keolahragaan Vol. 17 (2), Juli-Desember 2018: 62 - 72

Menurut Josef Nossek, (1982:3) " latihan adalah suatu proses atau dinyatakan dengn katalain, periode waktu yang berlangsung selama beberapa tahun, sampai atlet tersebut standard penampilan yang tinggi" Proses latihan yang baik dan benar harus memperhitungkan dan menyesuaikan volume, frekuensi, dan recovery internal, atau masa istirahat. Selama latihan, terutama prinsip beban berlebih ( overload principle) Harsono ( 1988 : 56) mengemukakan bahwa, " apabila beban latian terlalu ringan, maka berupa lamapun ia latihan, berapa seringpun ia berlatih, atau sampai bagaimana pun lelahnya ia mengulang - mengulang latihan itu, peningkatan prestasi tidak akan meningkat ".

Untuk mencapai suatu prestasi dalam olahraga, diperlukan latihan latihan yang dilakukan secara teratur dan berkesinambungan.Latihan yang dilakukan secara teratur dan berkesinambungan dapat dituangkan dalam program latian yang pada akhirnya dapat meningkatkan kemampuan fisik secara nyata sehingga dapat mencapai presatasi olahraga yang diharapkan.Prestasi olahraga tidak datang dengan sendirinya atau diperoleh dengan mudah, tetapi melalui usaha dan latihan yang benar secara intensif. Pelaksaan latihan harus berpedoman pada prinsip - prinsip latihan, sebagai dasar atau landasan-landasan adalah proses (adaptasi) manusia terhadap lingkungan.

\section{Prinsip Beban Berlebih}

Prinsip beban berlebih (overload) adalah bahwa beban yang diberikan kepada atlet haruslah cukup berat., serta harus diberikan berurang kali dengan intensitas yang tinggi. Karena kalau latihan dilakukan secara sistematis maka diharapkan tubuh atlet dapat menyesuaikan diri semaksimal mungkin kepada latihan berat yang diberikan, serta dapat bertahan terhadap gejal - gejala yang ditimbulkan dari latihan berat tersebut.

Baik gejala fisik maupun mental,pada penelitian ini merupakan program latihan jangka pendek selama 6 minggu maka beban berlebih akan diterapkan atlet anggar dengan penambahan repetisi disetiap pertemuannya dengan tujuan agara terjadi peningkatan daya ledak otot tungkai setipa pertemuan latihan.

Spesialisasi

Spesialisasi yaitu mencurahkan segala kemampuan baik fisik maupun psikis pada satu cabang olahraga tertentu. Spesialisasi yang akan dilakukan pada penelitian ini adalah dengan memfokuskan pada keteampilan menyerang dan bertahan terhadap peningkatan daya ledak otot tungkai.

\section{Intensitas latihan}

Latihan dikenakan intenssif jika latihan - latihan dilakukan memacu jantung atau kemampuan diri melakukan repitis maksimal beban pada zona latihan. Sebagai tolak ukur menetukan kadar intensitas latihan dengan cara menghitung denyut nadi maksimal (DNM) dengan rumus DNM = 220 - umur, dari hasil tersebut dapat ditentukan intensitas untuk atlet yang akan berlatih apakah dimulai dari $65 \%$ DNM, 75\% DNM hingga pada pertemuan akhirnya haarus mencapai $95 \%$ DNM.

Untuk melatih kekuatan ataupun daya ledak otot tungkai dapat dilakukan dengan mengukur kemampuan repetisi maksimal atlet sesuai dengan kemampuan masing - masing .Intensitas latihan atlet diharuskan berlatih melalaui suatu program latihan yang intensif yang dilandaskan pada penambahan beban selama 6 yaitu 18 kali pertemuan secara bertahap dari intensitas maksimal mereka. Intensitas latihan dapat dilakukan dengan cara Denyut Nadi Maksimal (DNM), system maksimal dari set dan repetisi maksimal yang mampu dilakukan oleh atlet anggar yang akan menjalani latihan.

\section{Kualitas Latihan}

Kualitas latihan adalah setiap latihan haruslah berisi latihan - latiahan yang bermanfaat dan yang jelas arah serta tujuan latihannya. Hal yang harus dilakukan agar kualitas latihan mencapaai target dan tujuan pada setiap latihan pada penelitian ini adalah dengan memberikan latihan naik turun tangga dan lari gawang untuk bermanfaat pada tujuan 
Zen Fadli, Mubarok Kurrahman Ritonga : Perbedaan Pengaruh Latihan Lompat Gawang Dan Naik Turun Tangga Terhadap Daya Ledak Otot Tungkai Pada Atlet Ekskul Anggar Man 2 Model Medan Tahun 2018

latihan perbedaan pengeruh latihan kemampuan otot tungkai terhadap atlet anggar, dan melakukan koreksi dan kontruktif sesegera mungkin apabila atlet anggar mebuat kesalahan.

\section{Variasi Latihan}

Variasi dalam latihan adalah kreasi, jenis dan variasi - variasi latihan yang diterapkan secara cerdik akan dapat menjaga terpelihaaranya fisik maupun mental atlet, sehingga dengan demikian timbulnya kebosanana beraltih sejauh mungkin dapat dihindari. Pada penelitian ini latihan harus diraancang sedemikan rupa dengan beberapa variasi gerkan untuk meningkatkan daya ledak otot tungkai melalui latihan naik turun tangga dan lari gawang. Dalam penelitian ini peneliti menggunakan lama latihan selama 18 kali pertemuan. Pertemuan pertama untuk melaksakan pre test dan pertemuan yang terakhir setelah ( ke 18), akan di istirahatkan $1-2$ hari untuk melaksakana post test. Frekuensi adalah berapa kali seseorang melakukan latihan yang cukup intensif dalam satu minggunya (Sajoto, 1993 :137).

Dalam menentukan frekuensi latihan harus benar - benar menentukan batas - batas kemampuan seseorang, karena bagaimana pun juga tubuh seseorang tidak dapat beradaftasi lebih cepat dari batas kemampuannya.

Apabila frekuensi latihan yang diberikan berlebihan akibatnya bukan percepatan hasil yang diperoleh tetapi dapat menyebabkan sakit yang bekesinambungan. Menurut fox dan Metheus dalam Sajoto ( $1988: 138$ ) dikemukakan bahwa frekuensi latihan 3 - 5 kali per minggu adalah cukup efektif. Sedangkan menurut Brooks dan Fahey dalam Sojoto ( 1933 : 138 ) mengemukakan bahwa latihan antara 20 - 60 menit dalam intensitas tidak terlalu tinggi,

\section{Hakikat Lompat Gawang}

$>$ Dalam unsur lompat gawang, pelari gawang memfokuskan pada pengulangan tiga langkah lari percepatan.

$>$ Dalam unsur melewati gawang, pelari gawang berusaha meminimalkan waktu melayang dan mempersiapkan diri untuk melakukan lari berikutnya

$\checkmark$ Karakteristik teknik

Delapan langkah menju ke gawang pertama (kaki tumpu ada diposisi depan pada balok strat). Posisi badan tegak dicapai lebih awal dari pada saat strat lompat

Tiga langkah diantara gawang-gawang ( pendek - panjang - pendek), posisi badan tinggi diantara gawang - gawang

1. Fase bertolak ( take off)

$\checkmark$ Karekteristik teknik

Posisi badan tinggi untuk sesuatu penyerangan ( attack),Dorongan lebih banyak kedepan dari pada ke atas ( berlari melewati gawang, dan bukannya melompati)

Sendi - sendi pinggang, lutut dan mata kaki dari kaki - topang dilluruskan sepenuhnya. Paha kaki depan diayun dengan cepat ke posisi horizontal.

2. Fase melawati gawang

Bertolak tepat depan gawang dengan bola kaki 2/3 dari langkah seluruh gawang.

Tungkai depan dirurunkan secara aktif secepat mungkin setelah melewati gawang. Mendarat aktif dan pada bola kaki ( tumit tidak menyentuh tanah pada saat sentuh tanah)

$\checkmark$ Kaki depan

Tungkai bawah kaki depan secara aktif diluruskan ke depan pada arah lari

Telapak kaki dari kaki depan ditekuk, Untuk gawang yang lebih tinggi togok dibungkukkan togok tidak berlebihan untuk gawang yang lebih rendah. Bahu tetap pararel dengan gawang

$\checkmark$ Kaki belakang

Kaki belakang ditarik mengikuti badan

Paha kaki belakang pararel dengan tanah saat melewati gawang, sudut antar paha dan tungkai bawah kira kira - kira 90 drajat.Mata kaki dari kaki belakang ditekuk dalam - 


\section{Jurnal Ilmu Keolahragaan Vol. 17 (2), Juli-Desember 2018: 62 - 72}

dalam. Jari jari kaki diangkat keatas ,Lutut kaki belakang dipertahankan tetap tinggi saat ini ditarik melawati gawang.

3. Fase mendarat

Tungkai pendarat adalah kaki.Mendarat pada bola kaki.

Badaan jangan condong ke belakang tetap dilipat sampai saat sentuh tanah kemudian ditarik dengan cepat dan aktif kedepan.

Kontak dengan tanah adalah singkat, langkah pertama agresif

\section{Hakikat Naik Turun Tangga}

Olahraga naik turun tangga adalah salah satu jenis olahraga yang efektif membakar lemak, olahraga ini juga efektif untuk menguatkan jantung dan meningkatkan ketahanan tubuh. Setiap menitnya, aktivitas naik tangga diperkirakan akan mengkonsumsi enegri (membakar kalori) sebanyak 8-11 kalori. Nilai ini merupakan nilai yang cukup tinggi jika dibandingkan dengan aktivitas olahraga dengan intensitas sedang seperti tenis, badminton, sepak bola dan juga basket, yang mengonsumsi energi sebanyak 7-9 kalori permenit.(Anggraeni, 2013).Pengertian latihan menurut Nurhasan (1986:23). Dalam I Gede Gunawan (2014). Latihan naik tangga dapat juga disebut harvard step, latihan naik turun tangga ini dilakukan bertujuan untuk peningkatan unsur kecepatan dan kekuatan pada kondisi fisik. Sebab unsur kecepatan dan kekuatan merupakan bagian mendasar pada daya tahan.

Daya tahan otot adalah kemampuan otot untuk menjalani kontraksi dengan beban sub maksimal secara berulang atau mempertahankan kontraksi otot dalam periode waktu tertentu. Jika kamu memiliki daya tahan otot yang baik maka kamu bisa melakukan keiatan yang lama tanpa mengalami kelelahan, tetapi sebaliknya jika kamu tidak memiliki daya tahan yang baik maka kamu mudah mengalami kelelahan.

Daya tahan seseorang bisa terus ditingkatkan melalui latihan naik turun tangga, latihan naik turun tangga ini bertujuan untuk meningkatkan daya tahan otot tungkai. Jika kamu memiliki daya tahan otot yang baik maka kamu bisa melakukan latian yang lama tanpa mengalami kelelahan yang berkelebihan., tetapi sebaiknya jika kamu tidak memiliki daya tahan yang baik maka kamu mudah merasakan kelelahan. Daya tahan seseorang bisa terus ditingkatkan melalui latihan naik turun tangga, karena latian ini bermanfaat untuk meningkatkan otot tungkai.

\section{METODE}

Metode penelitian memberikan garis-garis yang cermat dan mengajukan syaratsyarat yang keras, dengan maksud untuk menjaga agar pengetahuan yang dicapai dalam suatu penelitian dapat mempunyai kualitas ilmiah yang tinggi dan dapat dipertanggung jawabkan sesuai dengan aturan yang berlaku. (Sutrisno hadi,1987 : 4).

Lokasi pelaksanaan penilitian diadakan di Man 2 Model medan Jl.WiliamIskandar no 7A. BantanTimur, Medan Tembung, Kota Medan, Sumatera Utara. Waktu penelitian diadakan pada bulan Oktober 2018 dengan jumlah pertemuan sebanyak 16x dalam 1,5 bulan. Sebelum memulai latihan terlebih dahulu pengambilan data awal tentang power otot tungkai (pre test), selanjutnya pengambilan data terakhir (post test) dilaksanakan setelah program yang telah diberikan.

Populasi yang ada didalam penelitian ini adalah 20 atlet ekskulanggar Man 2 Model Medan. Sampel adalah sebagian yang diambil dan populasi dengan menggunakan cara - cara tertentu ( Sudjan 1992 : 161 ). Sampel yang digunakan sebanyak 20 orang. Berdasarkan hasil tes sempel dibagi menjadi 2 kelompok, yaitu kelompok naikturun tangga dan kelompok lompat gawang dengan masing masing kelompok berjumlah 10 orang. Dimana pembagian kelompok dilakukan dengan pilihan mereka.

Sesuai dengan permasalahan dan tujuanpenelitian yang diuraikan sebelumnya, 
Zen Fadli, Mubarok Kurrahman Ritonga : Perbedaan Pengaruh Latihan Lompat Gawang Dan Naik Turun Tangga Terhadap Daya Ledak Otot Tungkai Pada Atlet Ekskul Anggar Man 2 Model Medan Tahun 2018

bahwa penelitian ini dilakukan bermaksud untuk menemukan informasi tentang perbedaan pengaruh latian naik turun tangga dan lompat gawang terhadap daya ledak otot tungkai pada atlet ekskul anggar Man 2 Model Medan tahun 2018.

Sehubung hal diatas, maka penulis menggunakan metode yang dianggap sesuai dengan permasalahan yang hendak diteliti yaitu menggunakan metode eksperimen dengan menggunakan teknik total sampling dalam pengambilan sampel dan pengambilan data dengan menggunakan tes dan pengukuran. Ada dua variable bebas dalam penelitian ini yaitu latihan naik turun tangga dan latihan lompat gawang dan satu variable terikat yaitu otot tungkai.

Penelitian akan memberlakukan prinsip latihan over load (beban berlebih pada sampel. Agar kemampuan otot yang dilatih tidak menurun, maka latihan dilakukan 3 ( tiga ) kali seminggu.

Tabel Bentuk disain penelitian pre test dan post test one group design

\begin{tabular}{cccc}
\hline Pre test & Matcing Pairing & Perlakuan & Post test \\
\hline \multirow{2}{*}{ T1 } & Kelompok A & Naik turun tangga & \multirow{2}{*}{ T2 } \\
\cline { 2 - 3 } & Kelompok B & Lompat gawang & \\
\hline
\end{tabular}

Keterangan : T1 $=$ Tes Awal Standing Long Jump/ Broad Jump $\mathrm{T} 2=$ Tes Akhir Standing Long Jump/ Broad Jump

\section{HASIL}

Hasil tes dan pengukuran yang dilakukan di lapangan merupakan temuan peneliti yang dilakukan selama 18 pertemuan. Dilakukan untuk mengungkapkan kebenaran hipotesis, hasil tes dan pengukuran yang telah diolah melalui rumus statistik menunjukkan deskripsi data sebagai berikut :

Pre-Test dan Post-Test Latihan Lompat Gawang Dan Naik Turun Tangga Terhadap Daya Ledak Otot Tungkai Pada Atlet Ekskul Anggar Man 2 Model Medan Tahun 2018

\begin{tabular}{ccc}
\hline \multirow{2}{*}{ Deskripsi Data } & \multicolumn{2}{c}{ Hasil Standing Broad Jump } \\
\cline { 2 - 3 } & \multicolumn{2}{c}{ Latihan Lompat Gawang } \\
\cline { 2 - 3 } & Pre-test & Post-test \\
\hline Nilai Rata-Rata & $175,2 \mathrm{~cm}$ & $187,8 \mathrm{~cm}$ \\
\hline Simpangan Baku & 3.37 & 3.01 \\
\hline Beda Rata-Rata & \multicolumn{2}{c}{12.6} \\
\hline Simpangan Baku Beda & \multicolumn{2}{c}{1.835} \\
\hline
\end{tabular}

Dari hasil pre-test pada latihan Lompat Gawang terhadap hasil peningkatan daya ledak power otot tungkai, dengan nilai rata-rata 175,2 dan simpangan baku 3.37. Dari hasil post-test diperoleh nilai rata-rata 187,8 dan simpangan baku 3.01. Dari rata-rata pre-test dan post-test didapat nilai beda 12.6 dengan simpangan baku beda 10.3 
Jurnal Ilmu Keolahragaan Vol. 17 (2), Juli-Desember 2018: 62 - 72

\begin{tabular}{ccc}
\hline \multirow{2}{*}{ Deskripsi Data } & \multicolumn{2}{c}{ Hasil Standing Broad Jump } \\
\cline { 2 - 3 } & \multicolumn{2}{c}{ Latihan Naik Turun Tangga } \\
\cline { 2 - 3 } & Pre-test & Post-test \\
\hline Nilai Rata-Rata & $170.7 \mathrm{~cm}$ & $181.6 \mathrm{~cm}$ \\
\hline Simpangan Baku & 3.18 & 2.53 \\
\hline Beda Rata-Rata & \multicolumn{3}{c}{10.9} \\
\hline $\begin{array}{c}\text { Simpangan Baku } \\
\text { Beda }\end{array}$ & \multicolumn{2}{c}{1.706} \\
\hline
\end{tabular}

Dari hasil pre-test pada latihan Naik Turun Tangga terhadap hasil peningkatan daya ledak power otot tungkai, dengan nilai rata-rata 170.7 dan simpangan baku 3.18. Dari hasil post-test diperoleh nilai rata-rata 181.6 dan simpangan baku 2.53. Dari rata-rata pre-test dan post-test didapat nilai beda 10.9 dengan simpangan baku beda 1.706

Sebelum dilakukan analisis statistik, terlebih dahulu dilakukan uji asumsi atau pengujian persyaratan analisis yang meliputi uji normalitas dan uji homogenitas. Penggunaan uji normalitas digunakan untuk mengetahui normal atau tidaknya distribusi data yang diperoleh, sedangkan penggunaan uji homogenitas digunakan untuk mengetahui apakah sampel penelitian berasal dari populasi yang bersifat homogen. Hasil uji prasyarat analisis disajikan berikut ini:

Pengujian normalitas mengunakan uji liliefors. Dalam uji ini akan menguji hipotesis sampel berasal dari populasi berdistribusi normal, untuk menerima atau menolak hipotesis dengan membandingkan $\mathrm{L}_{0}$ dengan Tabel Nilai Kritis Untuk Uji Liliefors. Kriterianya Menerima hipotesis apabila Nilai Kritis L untuk Uji Liliefors yang lebih besar dari $\mathrm{L}_{0}$.

Tabel Uji Normalitas Lompat Gawang Pretest dan Postest

\begin{tabular}{lllll}
\hline No. & Variabel & $\mathrm{L}_{0}$ & $\mathrm{~L}_{\mathrm{t}}$ & Kesimpulan \\
\hline 1 & Hasil Pretest & 0,185 & 0,258 & \\
\cline { 1 - 4 } 2 & Hasil Postest & 0.168 & 0,258 & Normal \\
\hline
\end{tabular}

Dari tabel diatas, L yang berasal dari Nilai Kritis Uji Liliefors dengan Taraf nyata $\alpha$ : 0,05 lebih besar dari $\mathrm{L}_{0}$

Tabel Uji Normalitas Naik Turun Tangga Pretest dan Postest

\begin{tabular}{lllll}
\hline No. & Variabel & $\mathrm{L}_{0}$ & $\mathrm{~L}_{\mathrm{t}}$ & Kesimpulan \\
\cline { 1 - 4 } 1 & Hasil Pretest & 0,171 & 0,258 & Normal
\end{tabular}

Dari tabel diatas, L yang berasal dari Nilai Kritis Uji Liliefors dengan Taraf nyata $\alpha$ : 0,05 lebih besar dari $\mathrm{L}_{0}$.

Uji homogenitas dilakukan untuk mengetahui kesamaan variansi, atau untuk menguji bahwa data yang diperoleh berasal dari populasi yang homogen, untuk menerima atau menolak hipotesis dengan membandingkan nilai signifikan lebih dari 0,05 . Hasil uji homogenitas dapat dilihat pada tabel di bawah ini.

Tabel Hasil Uji Homogenitas Lompat Gawang

\begin{tabular}{llll}
\hline Variabel & $\mathrm{F}_{\mathrm{h}}(\mathrm{F}$-hitung $)$ & $\mathrm{F}_{\mathrm{t}}(\mathrm{F}$-table $)$ & Kesimpulan \\
\cline { 1 - 1 } Pretest & & & \\
\cline { 1 - 1 } Postest & 1.836 & 3.179 & Homogen \\
\hline
\end{tabular}

Kesimpulan yang didapat pada tabel di atas adalah, Jika Fh $<$ Ft maka Ho diterima. Jadi, $1.836<3.179$ maka hipotesis diterima. 
Zen Fadli, Mubarok Kurrahman Ritonga : Perbedaan Pengaruh Latihan Lompat Gawang Dan Naik Turun Tangga Terhadap Daya Ledak Otot Tungkai Pada Atlet Ekskul Anggar Man 2 Model Medan Tahun 2018

Tabel Hasil Uji Homogenitas Naik Turun Tangga

\begin{tabular}{cccc}
\hline Variabel & $\mathrm{F}_{\mathrm{h}}(\mathrm{F}$-hitung $)$ & $\mathrm{F}_{\mathrm{t}}(\mathrm{F}$-table $)$ & Kesimpulan \\
\cline { 1 - 1 } Pretest & \multirow{2}{*}{1.705} & 3.179 & Homogen
\end{tabular}

Kesimpulan yang didapat pada tabel di atas adalah, Jika Fh $<$ Ft maka Ho diterima. Jadi, $1.705<3.179$ maka hipotesis diterima.

Pengujian hipotesis dilakukan dengan uji-t pada data pretest dan postest hasil tes daya ledak otot tunggkai pada atlet ekskul anggar Man 2 model medan . Analisis data yang digunakan untuk menjawab hipotesis yang diajukan yaitu ada tidaknya pengaruh latihan lompat gawang dan naik turun tangga terhadap daya ledak otot tunggkai pada atlet ekskul anggar Man 2 model Medan, yaitu sebagai berikut:

Ho : Latihan lompat gawang berpengaruh terhadap daya ledak otot tungkai pada atlet ekskul anggar man 2 model medan.

Ha : Latihan Naik turun tangga berpengaruh terhadap daya ledak otot tungkai pada atlet ekskul anggar man 2 model medan.

Untuk mengetahui ada atau tidak adanya pengaruh signifikan dari latihan lompat gawang dan naik turun tangga terhadap daya ledak otot tungkai atlet ekskul anggar man 2 model medan, maka dilakukan uji-t. Hasil uji-t terangkum dalam tabel berikut.

Tabel Hasil Uji-t Lompat Gawang Pretest dan Postest

\begin{tabular}{cccccc}
\hline Variabel & Rata-rata & $\mathrm{t}_{\text {hitung }}$ & $D f$ & $\mathrm{t}_{\text {tabel }}$ & Keterangan \\
\cline { 1 - 2 } Pretest & 175,2 & \multirow{2}{*}{3.058} & 9 & \multirow{2}{*}{1.83} & Signifikan \\
\cline { 1 - 2 } Postest & 187,8 & & & & \\
\hline
\end{tabular}

Hasil uji-t diperoleh nilai t-hitung sebesar 3.058 dan nilai t-tabel sebesar 1.833. Oleh karena nilai t-hitung lebih besar dari t-tabel $(3.057>1.83)$ dengan taraf segnifikan $\alpha: 0,05$ maka dapat disimpulkan bahwa terdapat pengaruh Latihan Lompat gawang terhadap daya ledak otot tungkai pada atlet ekskul anggar man 2 model medan.

Berdasarkan tabel di atas dapat diketahui bahwa nilai rata-rata untuk data pretest adalah sebesar 175,2 dan nilai rata-rata untuk data postest adalah sebesar 187, Dalam hal ini dapat disimpulkan peningkatan yang diberikan dengan Lompat gawang terhadap daya ledak otot tungakai atlet ekskul anggar man 2 model medan meningkat.

Tabel Hasil Uji-t Naik Turun Tangga Pretest dan Postest

\begin{tabular}{llllll} 
Variabel & Rata-rata & $\mathrm{t}_{\text {hitung }}$ & $D f$ & $\mathrm{t}_{\text {tabel }}$ & Keterangan \\
\hline Pretest & 170,7 & & & & \\
\cline { 1 - 2 } Postest & 181,6 & 3.587 & 9 & 1.83 & Signifikan \\
\hline
\end{tabular}

Hasil uji-t diperoleh nilai t-hitung sebesar 3.587 dan nilai t-tabel sebesar 1.83. Oleh karena nilai t-hitung lebih besar dari t-tabel (3.587 > 1.83) dengan taraf segnifikan $\alpha: 0,05$ maka dapat disimpulkan bahwa terdapat pengaruh Latihan Naik turun tangga terhadap daya ledak otot tungkai pada atlet ekskul anggar man 2 model medan. Berdasarkan tabel di atas dapat diketahui bahwa nilai rata-rata untuk data pretest adalah sebesar 170,7 dan nilai ratarata untuk data postest adalah sebesar 181,6.Dalam hal ini dapat disimpulkan peningkatan yang diberikan dengan Naik turun Tangga terhadap daya ledak otot tungakai atlet ekskul anggar man 2 model medan. 
Jurnal Ilmu Keolahragaan Vol. 17 (2), Juli-Desember 2018: 62 - 72

\section{PEMBAHASAN}

Pengelolaan data yang dilakukan dengan analisis uji-t dari hasil pretest dan pos tes menunjukkan. Hasil uji-t diperoleh nilai t-hitung sebesar 3.057 dan nilai t-tabel sebesar 1.83. Oleh karena nilai t-hitung lebih besar dari t-tabel $(3.057>1.83)$ maka dapat disimpulkan bahwa terdapat pengaruh latihan Lompat gawang terhadap daya ledak otot tungkai pada atlet ekskul anggar man 2 model medan.Berdasarkan tabel di atas dapat diketahui bahwa nilai rata-rata untuk data pretest adalah sebesar 175,2 dan nilai rata-rata untuk data postest adalah sebesar 187,8 .

Menurut Amin, Muhammad and Insanistyo, Bayu and Sutisyana, Ari (2014) Judul Jurnal (Pengaruh Latihan Lompat Gawang Terhadap Peningkatan Daya Ledak Otot Tungkai Pada Atlet Bulutangkis Klub Pb Citra Kecamatan Argamakmur Kabupaten Bengkulu Utara) Penelitian ini bertujuan untuk mengetahui berapa besar pengaruh latihan lompat gawang pada atlet bulutangkis klub PB Citra Kecamatan Arga makmur Kabupaten Bengkulu Utara. Penelitian ini merupakan penelitian eksperimental. Populasi penelitian yang digunakan adalah atlet bulutangkis putra klub PB Citra umur 13 - 15 tahun berjumlah 30 atlet. Teknik pengumpulan data menggunakan metode tes vertical Jump. Dengan validitas tes sebesar 0,989 dan reliabilitasnya sebesar 0,977 . Teknik analisis dalam penelitian ini menggunakan koefesian determinasi.

Data yang diperoleh menunjukan criteria sedang, cukup, dan baik. Hasil penelitian menunjukan penghitungan statistic diperoleh nilai pengaruh sebesar 90,25\% yang menunjukan besar pengaruh latihan lompat gawang. Dengan demikian, latihan lompat gawang memiliki pengaruh yang signifikan. Kesimpulan data saya sama dengan hasil jurnal yang saya kutip

Penelitian ini bertujuan untuk mengetahui, pengaruh latihan naik turun tangga terhadap daya ledak otot tungkai pada atlet ekskul anggar Man 2 model medan . Hasil penelitian menunjukkan bahwa terdapat peningkatan kemampuan daya ledak otot tungkai setelah mendapat perlakuan latihan lompat gawang.

Hasil uji-t diperoleh nilai t-hitung sebesar 3.587 dan nilai t-tabel sebesar 1.83. Oleh karena nilai t-hitung lebih besar dari t-tabel (3.587 > 1.83) maka dapat disimpulkan bahwa terdapat pengaruh Latihan Naik turun tangga terhadap daya ledak otot tungkai pada atlet ekskul anggar man 2 model medan. Berdasarkan tabel di atas dapat diketahui bahwa nilai rata-rata untuk data pretest adalah sebesar 170,7 dan nilai rata-rata untuk data postest adalah sebesar 181,6. Menurut Fardede Pujiansyah Ismail,Arwin,Tono Sugihartono (2017) Judul jurnal (Perbedaan Latihan Naik Turun Tangga Tunggal (Satu Tangga) Dengan Naik Turun Tangga Jamak (Enam Tangga) Terhadap Kemampuan Lari Sprint 60 Meter Siswa Kelas V Sd Negeri 69 Kota Bengkulu.) Penelitian ini bertujuan untuk mengetahui perbedaan latihan naik turun tangga tunggal (satu tangga) dengan latihan naik turun tangga jamak (enam tangga) untuk menentukan latihan mana yang baik digunakan untuk meningkatkan kemampuan lari sprint 60 meter siswa kelas V SD 69 Kota Bengkulu. Jenis penelitian ini adalah penelitian kuantitatif dengan metode penelitian menggunakan Eksprimen kuasi. Sampel pada peneletian ini adalah siswa kelas V SD Negeri 69 Kota Bengkulu yang berjumlah 40 siswa. Hasil penelitian menunjukkan ada perbedaan yang signifikan antara tangga tunggal (satu tangga) dengan latihan naik turun tangga jamak (enam tangga) dengan t-hitung 2,278 dan t-tabel 2,101. Yang menunjukkan bahwa t-hitung lebih besar dari thitung maka terdapat perbedaan antara tangga tunggal (satu tangga) dengan latihan naik turun tangga jamak (enam tangga). Kesimpulan data saya sama dengan hasil jurnal yang saya kutip.

Penelitian ini dilaksanakan di sekolah Man 2 model medan lokasi Helvetia medan. Penelitian ini dilaksanakan dari bulan 1November - 15 Desember 2018 dengan 18 kali pertemuan. Populasi dalam penelitian ini adalah seluruh Atlet ekskul anggar man 2 model 
Zen Fadli, Mubarok Kurrahman Ritonga : Perbedaan Pengaruh Latihan Lompat Gawang Dan Naik Turun Tangga Terhadap Daya Ledak Otot Tungkai Pada Atlet Ekskul Anggar Man 2 Model Medan Tahun 2018

medan yang berjumlah 20 orang dan jumlah sampel penelitian sebanyak 10 atlet lompat gawang dan 10 naik turun tangga, sampel dipilih berdasarkan . anak yang menjadi sampel penelitian, untuk memproleh data dalam penelitian ini dipergunakan instrumen test Standing Broad Jump sebuah tes yang digunakan untuk mengukur kemampuan daya ledak otot tungkai Pada atlet ekskul anggar Man 2 model medan.

Tujuan dari Test Standing Broad Jump seberapa jauh kekuatan daya ledak otot tungkai dan keuatan daya tahan otot tungkai, Dari data pretest diketahui rata-rata yaitu sebesar 3,459. Setelah melaksanakan pretest,atlet diberikan latihan d untuk memperbaiki daya ledak otot tungkai dengan latihan lompat gawang naik turun tangga. Lompat gawang pada prinsipnya latihan melompati pipa yang dibentuk menyerupai tiang gawang dan naik turun tangga sebanyak 32 anak tangga. Dari pengujian hipotesis tabel perhitungan uji - $\mathrm{t}$ data post test power otot antara latihan lompat gawang dan latihan naik turun tangga. Lompat gawang dari hasil perhitungan uji - t Post test kelompok latihan lompat gawang diperoleh t-hitung sebesar 5.47 dan Bedasarkan tabel daftar distribusi t dengan $\mathrm{dk}=\mathrm{n}-1(10-1=9)$ pada taraf nyata $\alpha=$ $0,05=1,83$ yang berarti $t_{\text {hitung }}>t_{\text {tabel }}(5.47>1.83)$ dengan demikian $H_{a}$ diterima dan $H_{0}$ ditolak. Dari hasil Perhitungan uji - t Post test kelompok latihan Naik Turun Tangga diperoleh t-hitung sebesar 2.06 dan Bedasarkan tabel daftar distribusi t dengan dk $=\mathrm{n}-1(10-$ $1=9)$ pada taraf nyata $\alpha=0,05=1,83$ yang berarti $t_{\text {hitung }}>t_{\text {tabel }}(2.06>1.83)$ dengan demikian $\mathrm{H}_{\mathrm{a}}$ diterima dan $\mathrm{H}_{0}$ ditolak.

Dapat disimpulkan bahwa latihan lompat gawang lebih baik dari latihan naik turun tangga terhadap Hasil Daya Ledak Otot Tungkai Pada Atlet Ekskul Anggar Man 2 Model Medan Tahun 2018.

\section{KESIMPULAN DAN SARAN}

Berdasarkan hasil analisis data, pengujian hipotesis dan pembahasan yang telah dikemukakan pada bab sebelumnya, kesimpulan dalam penelitian ini adalah:

lompat gawang dan naik turun tangga yang lebih pengaruh adalah lompat gawang dibanding naik turun tangga setelah dilihat dari perbandingan hasil pree test dan post test masing masing varians Lompat gawang dan Naik Turun tangga sebesar $12.6>10.9$.

Dari pengujian hipotesis tabel perhitungan uji - $t$ data post test power otot antara latihan lompat gawang dan latihan naik turun tangga. Lompat gawang dari hasil perhitungan uji - $\mathrm{t}$ Post test kelompok latihan lompat gawang diperoleh t-hitung sebesar 5.47 dan Bedasarkan tabel daftar distribusi t dengan $\mathrm{dk}=\mathrm{n}-1(10-1=9)$ pada taraf nyata $\alpha=0,05=$ 1,83 yang berarti $t_{\text {hitung }}>t_{\text {tabel }}(5.47>1.83)$ dengan demikian $\mathrm{H}_{\mathrm{a}}$ diterima dan $\mathrm{H}_{0}$ ditolak.

Dari hasil Perhitungan uji $-\mathrm{t}$ Post test kelompok latihan Naik Turun Tangga diperoleh t-hitung sebesar 2.06 dan Bedasarkan tabel daftar distribusi t dengan dk $=\mathrm{n}-1(10-$ $1=9)$ pada taraf nyata $\alpha=0,05=1,83$ yang berarti $t_{\text {hitung }}>t_{\text {tabel }}(2.06>1.83)$ dengan demikian $\mathrm{H}_{\mathrm{a}}$ diterima dan $\mathrm{H}_{0}$ ditolak.

Dapat disimpulkan bahwa latihan lompat gawang lebih baik dari latihan naik turun tangga terhadap Hasil Daya Ledak Otot Tungkai Pada Atlet Ekskul Anggar Man 2 Model Medan Tahun 2018.

Berdasarkan hasil penelitian yang dilakukan, saran yang dapat diberikan adalah sebagai barikut:

1. Bagi atlet ekskul Man 2 model medan latihan lompat gawang dan naik turun tangga merupakan salah satu bentuk latihan yang dapat meningkatkan daya ledak otot tungkai.

2. Bagi pelatih diharapkan dapat lebih memahami kebutuhan dan kelamahan atlet, agar dapat memperbaiki gerakan gerakan dasar latihan anggar yang lebih dominan di otot tungkai. 
Jurnal Ilmu Keolahragaan Vol. 17 (2), Juli-Desember 2018: 62 - 72

3. Bagi peneliti selanjutnya, agar menambah subyek penelitian dengan ruang lingkup yang lebih besar dan dengan perlakuan atau model latihan yang lebih bervariasi.

\section{DAFTAR PUSTAKA}

Amin, Muhammad and Insanistyo, Bayu and Sutisyana, Ari (2014). (Pengaruh L atihan Lompat Gawang Terhadap Peningkatan Daya Ledak Otot Tungkai Pada Atlet Bulutangkis Klub Pb Citra Kecamatan Argamakmur Kabupaten Bengkulu Utara) Jurnal Ilmiah Pendidikan Jasmani, 1 (1) 2014. ISSN 2833-5522

Bompa Periodization danBompathory and Methodologi "Latihan"

Evelyn C. Pearce AnatomidanFisiologiuntukParamadis "Otot Tungkai"

Elaine Cheris diterjemahkan oleh Meyjen TNI Tono Suratman"Olahraga Anggar dan Sejarah Anggar"

Dr.DikdikZafar SidikM.Pd “ MengajardanmelatihAtletik”

Fardede Pujiansyah Ismail,Arwin,Tono Sugihartono (2017) (Perbedaan Latihan Naik Turun Tangga Tunggal (Satu Tangga) Dengan Naik Turun Tangga Jamak (Enam Tangga) Terhadap Kemampuan Lari Sprint 60 Meter Siswa Kelas V Sd Negeri 69 Kota Bengkulu.) Jurnal urnal Ilmiah Pendidikan Jasmani, 1 (1) 2017. ISSN 2477-3311

Sajoto. (1988). Pembinaan Kondisi Fisik Dalam Olahraga.Jakarta, Departemen Pendidikan dan Kebudayaan.

Sudjana. (1992). Statistik, Bandung, Tarsito.

Sugiyono. (2016). Metode Penelitian Kuantitatif Kualitatif dan R\&D. Bandung : Alfabeta

Sajoto, M. Pembinaandan Peninkatan Kondisi Fisik dalam Olahraga. Semarang, Dahara Prize, 1995. 